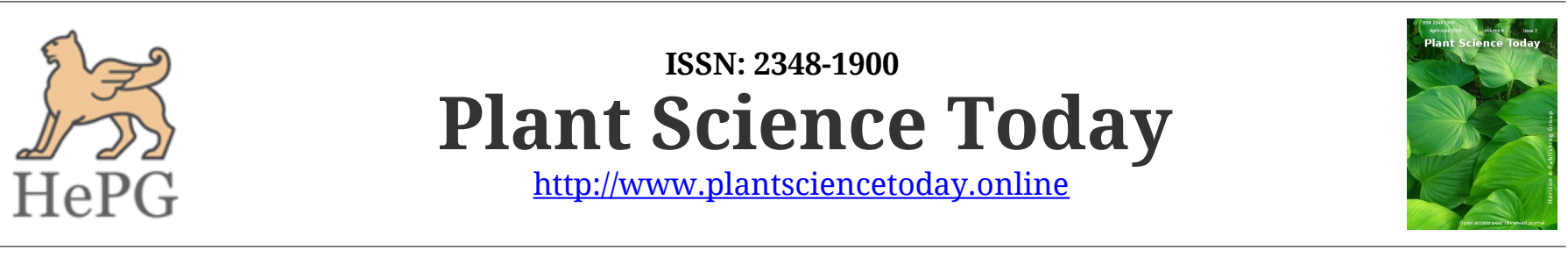

OPEN ACCESS

Research Article

\title{
Pollen morphology of Myrtaceae visited by social bees
}

\author{
A S Nascimento*, C A L Carvalho \\ Centro de Ciências Agrárias, Ambientais e Biológicas, Universidade Federal do Recôncavo da Bahia, 44380-000, Cruz das Almas, BA, Brazil
}

\section{Article history}

Received: 04 January 2019

Accepted: 07 March 2019

Published: 01 April 2019

\section{Editor}

Prof. Sahar A.A. Malik Al-Saadi University in Basra

Basra, Iraq

\section{Publisher}

Horizon e-Publishing Group

\author{
*Correspondence \\ A S Nascimento \\ $\square$ asndea@gmail.com
}

\begin{abstract}
This study aimed to characterize species of Myrtaceae belonging to genera already identified in the pollen spectrum of beehive products of social bees, describing pollen grains morphology and correlating with taxonomic differences the species reported in the literature. For each plant species, measurements were made with 25 pollen grains in equatorial view and the polar diameter (PD) and equatorial diameter (ED) were measured. The exine thickness was obtained by measuring 10 pollen grains in polar view at the medium height of mesocolpium. The description of pollen morphology showed that pollen grains of the species are triangular $a m b$, 3-colporates, psilate surface, small to medium size and oblate shape with the $\mathrm{P} / \mathrm{E}$ ratio ranging from 0.52 to $0.72 \mu \mathrm{m}$. The morphological description of Myrtaceae species showed similarity between several characteristics common to pollen grains of this species. The description also allowed separation of nine species studied by size and specific morphological characters with the identification key, which can also be used to study the pollen spectrum of hive products.
\end{abstract}

Keywords: Pollen grain; palynotaxonomy; plant; bee flora.

Citation: Nascimento AS, Carvalho CAL. Pollen morphology of Myrtaceae visited by social bees. Plant Science Today 2019;6(2):98-105. https://doi.org/10.14719/pst.2019.6.2.475

Copyright: (c) Nascimento \& Carvalho (2019). This is an open-access article distributed under the terms of the Creative Commons Attribution License, which permits unrestricted use, distribution, and reproduction in any medium, provided the original author and source are credited (https://creativecommons.org/licenses/by/4.0/).

Indexing: Plant Science Today is covered by Scopus, CAS, AGRIS, CABI, Google Scholar, etc. Full list at http://www.plantsciencetoday.online

\section{Introduction}

The study of bee flora indicates food sources that bees use to collect nectar and pollen, allowing to maximize the use of natural resources, both in the establishment and upkeep of local apicultural flora, in areas of natural or cultivated vegetation (1-2). Several botanical families stand out as nectar and pollen sources for bees and different studies (3-5) have reported Myrtaceae as one of the most important. However, studies on palynotaxonomy of apicultural plants are scarce and our study is the first to correlate pollen morphology of Myrtaceae to bee flora.
Myrtaceae is considered of great ecological relevance, since this family presents characteristics of apicultural plants (pollen and nectar production), besides producing edible fruits, highly appreciated by wild fauna and humans (6-7). Additionally, Myrtaceae is among the most diversified families in Brazilian vegetation formations (8-9).

With roughly 140 genera and more than 3000 species, the Myrtaceae family has its two main dispersion centers in the Americas and Australia. In Brazil, there are approximately 1000 species described and distributed in 23 genera (10-12). The genera of Myrtaceae belonging to the 
Leptospermoideae subfamily with greater diversity of species are Eucalyptus (500 species) and Malaleuca (100 species). For the Myrtoideae subfamily are Eugenia (600 species), Myrcia (300 species), Syzygium (200 species) and Psidium (100 species) (13).

Among the exotic species of Myrtaceae in Brazil, the genera Eucalyptus (with many timber and essential oil species), Callistemon and Mellaleuca (as ornamental species) stand out. Other species of relevance are Pimenta dioica and Syzygium aromaticum (used as spices in culinary), besides the fructiferous genera Eugenia uniflora, $S$. cumini and S. malaccensis (14-16).

The potential of eucalyptus for honey production is well known and both beekeepers and foresters explore this potential to generate extra income from their eucalyptus crops. Eucalyptus flowers are very attractive to bees because of high pollen and nectar concentrations, ideal for good development of hives (17-18). The Eucalyptus species have variable pollen production and sometimes are classified as nectariferous or polliniferous (19).

Studies on the botanical identity of pollen in honey or bee pollen from the state of Bahia, Brazil, highlight the Myrtaceae as one of the most important families for the sustainable development of beekeeping and meliponiculture (5,20-21). However, identification of the botanical affinity of pollen types in bee products is not always an easy task. Myrtaceae is considered stenopalynous, with pollen grains peroblates to suboblates, isopolar or heteropolar, radial, 3-colporate, biconvex, convex or concave-convex plane, triangular or subtriangular amb (outline of a pollen grain seen in polar view), with perforated exine or psilate (22). These complex taxonomic characteristics are important tools to identify pollen types in bee products.

Our study aimed to characterize species of Myrtaceae belonging to genera identified in the pollen spectrum of beehive products of social bees in the Recôncavo of Bahia, Brazil, describing the morphology of pollen grains and correlating with taxonomic differences reported in the literature. The results obtained may be useful in the characterization of hive products. This is the first work that correlates palynotaxonomy of Myrtaceae with bee flora.

\section{Material and methods \\ Sampling and site study}

We selected species Eucalyptus alba Reinw. ex Blume, Eucalyptus sp.I, Eucalyptus sp.II, Eucalyptus torelliana F. Muell., Eugenia uniflora L., Psidium araca Raddi, Psidium guajava L., Syzygium cumini (L.) Skeels and Syzygium malaccensis L. The species were selected based on studies that report the importance of Myrtaceae species as a trophic resource used by social bees (Table 1). The vegetal material was collected and herborized to identify the taxons. The samples were collected in the municipality of Cruz das Almas, located in the Recôncavo of Bahia (12 $42^{\prime} 12^{\prime \prime}$ S; 39 06' 07" W and altitude $220 \mathrm{~m}$ ) (Brazil) in the Atlantic Forest biome.

\section{Sample preparation}

Flower buds were collected from each species to prepare the slides for microscopy with the respective polliniferous materials, using the

Table 1. Species of Myrtaceae identified as trophic resources for social bees (Hymenoptera: Apidae).

\begin{tabular}{|c|c|c|c|}
\hline $\begin{array}{l}\text { Species / } \\
\text { Pollen Type }\end{array}$ & $\begin{array}{l}\text { Beehive products / flora } \\
\text { visited by bees }\end{array}$ & Bee species & Source \\
\hline Eucalyptus sp. & $\begin{array}{l}\text { honey; stored pollen; flora } \\
\text { visited }\end{array}$ & $\begin{array}{l}\text { Apis mellifera L.; Melipona scutellaris } \\
\text { Latreille. }\end{array}$ & $\begin{array}{l}\text { Nascimento et al. (4-5); } \\
\text { Oliveira et al. (20) }\end{array}$ \\
\hline Eucalyptus torelliana F. Muell. & flora visited & Apis mellifera $\mathrm{L}$. & Nascimento et al. (5) \\
\hline Eugenia sp. & honey & $\begin{array}{l}\text { Melipona mandacaia Smith; } \\
\text { Melipona scutellaris Latreille. }\end{array}$ & Santana et al. (3) \\
\hline Eugenia uniflora L. & honey & $\begin{array}{l}\text { Melipona asilvai Moure; Apis } \\
\text { mellifera L. }\end{array}$ & $\begin{array}{l}\text { Santana et al. (3); } \\
\text { Nascimento et al. (4) }\end{array}$ \\
\hline Eugenia uvalha L. & honey & Melipona quadrifasciata Lepeletier. & Santana et al. (3) \\
\hline Psidium araca Raddi. & flora visited & Apis mellifera L. & Nascimento et al. (5) \\
\hline Psidium guajava L. & honey & Scaptotrigona tubiba Smith. & Santana et al. (3) \\
\hline Psidium guajava L. & honey; flora visited & Apis mellifera $\mathrm{L}$. & Nascimento et al. (4-5) \\
\hline Psidium sp. & honey; stored pollen & $\begin{array}{l}\text { Tetragonisca angustula Latreille; } \\
\text { Melipona scutellaris Latreille. }\end{array}$ & $\begin{array}{l}\text { Santana et al. (3); Oliveira } \\
\text { et al. (20) }\end{array}$ \\
\hline Syzygium cumini (L.) Skeels & flora visited & Apis mellifera L. & Nascimento et al. (5) \\
\hline Syzygium malaccensis L. & flora visited & Apis mellifera L. & Nascimento et al. (5) \\
\hline Syzygium sp. & honey & Apis mellifera L. & Nascimento et al. (4) \\
\hline
\end{tabular}


standard method of acetolysis (23). After assembly of the pollen material on slides for microscopy images were captured, photomicrographs of pollen grains in equatorial and polar views of each species, within a maximum of seven days. We use a microscope Olympus (CH30) with a digital camera (Moticam-2300) coupled. All photomicrographs were captured with the 100x objective.

\section{Pollen morphology}

For each plant species, measurements were made with 25 grains of pollen in equatorial view, measuring the polar diameter (PD) and equatorial diameter (ED). The exine thickness was obtained by measuring 10 pollen grains in polar view at the medium height of mesocolpium. Morphological descriptions were based on specialized literature (24-26). Morphometric measurements were performed using Motic Imagens Plus 2.0ML software.

\section{Statistical analysis}

We performed the descriptive statistical analysis, calculating the arithmetic mean $(\overline{\mathrm{x}})$, the standard

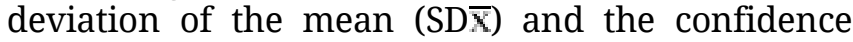
interval (95\%) of the respective diameters, as well as the $\mathrm{P} / \mathrm{E}$ ratio. In addition, Principal Component Analysis (PCA) was used to identify the similarity of species of Myrtaceae. The linear correlation coefficient was also calculated by the Euclidean Distance Matrix (EDM), using PAST 3.x software version 3.20, April 2018 (27).

\section{Results and Discussion}

The description of the pollen morphology of the species Myrtaceae evaluated in our study with the respective averages of diameters and thicknesses of exine are presented in Table 2 and 3 . The pollen grains of Myrtaceae presented triangular $a m b$, 3colporates, regularly parasyncolpate aperture type, psilate surface of exine, oblate shape and size of small to medium.

Myrtaceae pollen is trizonocroporate, isopolar and radiosimetric. Triangular in polar view, with apertures at the angles and elliptic in equatorial view. Small to medium size (28-30). According to Silva et al. (31), pollen grains of this family are peroblates to suboblates, isopolar or hetero-polar, radial and with exine perforated or psilate. These characteristics were also observed for the species analyzed in our study (Table 2-3 and Fig. 1).

Erdtman (32) considered the Myrtaceae family relatively stenopalynous in a study of 45 species of 30 genera. Silva et al. $(22,31)$ also reported this characteristic. Stenopalynous taxons present great similarity in pollen morphology within the group, hindering separation of individuals (33).

Barth (34) found a like result for E. uniflora, P. araca and P. guajava for Myrcia rostrata D.C., which, according to this author, presents small pollen grains, 3-colporates, oblate spheroids, measuring $13.5 \times 17.5 \mu \mathrm{m}$, long and strait colpus, rarely syncolpates, circular endo-apertures (4.5 $\mu \mathrm{m})$, triangular $a m b$, with a smooth surface exine. This author (34) also reports that pollen grains of Myrcia type were found as accessory pollen in two honey samples from the state of Bahia, indicating the importance of Myrtaceae species for the collection of trophic resources by social bees.

There was variation between the measurements for the Myrtaceae species within the same genus and different genera (Table 3). In addition, we performed the Principal Component Analysis (PCA), which revealed the greatest similarity between Eucalyptus alba and Eucalyptus sp.II, influenced by measurements of the polar diameter (PD). Eucalyptus sp.I and Eucalyptus torelliana presented measurements that were more similar with greater contribution of the equatorial diameter (ED) (Fig. 2). The first two main components accounted for $99.85 \%$ of the total variability of the results analyzed. The Euclidean Distance Matrix (EDM) confirmed the PCA results (Table 4) and E. alba x Eucalyptus sp.I were the nearest $(\mathrm{d}=2.64)$; Eucalyptus sp.II x E. alba $(\mathrm{d}=2.06)$ and E. torellina $\mathrm{x}$ Eucalyptus sp.II $(\mathrm{d}=1.96)$.

A study carried out with three species of Eucalyptus showed that the species presented size varying between small and medium, triangular $a m b$, 3-colporate, syncolpates, exine thickness \pm 2.1 $\mu \mathrm{m}$ and psilate surface (35), similar to our results (Table 2-3).

Takeda et al. (36) described the pollen morphology of Eugenia involucrata DC. as pollen grains of small size, tricolporate, angulaperturate, peroblate, with the $\mathrm{P} / \mathrm{E}$ ratio of $0.38 \mu \mathrm{m}$. We found a similar result for E. uniflora in our study, with variation in the $\mathrm{P} / \mathrm{E}$ ratio of $0.64 \mu \mathrm{m}$; however, the pollen grain was also classified as small size.

For Psidium guineense, Matos et al. (37) observed small pollen grain; prolate; tricolporate/tetracolporate, psilate and micoreticulate, the $\mathrm{P} / \mathrm{E}$ ratio of $1.38 \mu \mathrm{m}$. Comparing the results of our study for species of the same genus ( $P$. araca and $P$. guajava) shows that some morphological characteristics, such as size and shape, are evident for separation of these species (Table 3). The pollen grain morphology for Psidium species is useful to distinguish similarity between species of this group, and the exine ornamentation, the polar diameter in equatorial view and shape of the pollen grains are the most relevant morphological features (38).

The Eucalyptus species presented higher exine thickness (Table 3), while the lowest thickness was recorded for Syzygium species. Comparing the two species of genus Syzygium, we observed that $S$. malaccensis L. presented the lowest $\mathrm{P} / \mathrm{E}$ ratio $(0.52 \mu \mathrm{m})$. The Eucalyptus species stood out, because all presented pollen grains of 
Table 2. Description of the pollen morphology of Myrtaceae species visited by social bees (Apidae) in Cruz das Almas, Recôncavo region of Bahia, Brazil.

\begin{tabular}{lcccccc}
\hline Species/Myrtaceae & $\begin{array}{c}\text { amb } \\
\text { (outline) }\end{array}$ & Size & Surface & Aperture type & Aperture number & Fig. 1 \\
\hline Eucalyptus alba Reinw. ex Blume & triangular & medium & psilate & parasyncolpate & 3-colporates & A-B \\
Eucalyptus sp. I & triangular & medium & psilate & parasyncolpate & 3-colporates & C-D \\
Eucalyptus sp. II & triangular & medium & psilate & parasyncolpate & 3-colporates & E-F \\
Eucalyptus torelliana F. Muell. & triangular & medium & psilate & parasyncolpate & 3-colporates & G-H \\
Eugenia uniflora L. & triangular & small & psilate & parasyncolpate & 3-colporates & I-J \\
Psidium araca Raddi. & triangular & small & psilate & parasyncolpate & 3-(4)-colporates & K-M \\
Psidium guajava L. & triangular & small & psilate & parasyncolpate & 3-colporates & N-O \\
Syzygium cumini (L.) Skeels & triangular & small & psilate & parasyncolpate & 3-colporates & P-Q \\
Syzygium malaccensis L. & triangular & small & psilate & parasyncolpate & 3-colporates & R-T \\
\hline
\end{tabular}

Table 3. Dimensions of pollen grains of Myrtaceae species visited by social bees (Apidae) in Cruz das Almas, Recôncavo region of Bahia, Brazil.

\begin{tabular}{|c|c|c|c|c|c|c|c|c|}
\hline \multirow{2}{*}{$\begin{array}{c}\text { Species/ } \\
\text { Myrtaceae } \\
(n=9)\end{array}$} & \multicolumn{2}{|c|}{$\begin{array}{c}\text { PD } \\
(n=25)\end{array}$} & \multicolumn{2}{|c|}{$\begin{array}{c}\text { ED } \\
(n=25)\end{array}$} & \multicolumn{4}{|c|}{ Exine thickness } \\
\hline & $\begin{array}{c}\operatorname{Mean} \pm S D \\
(\mu \mathrm{m})\end{array}$ & $\begin{array}{c}\text { CI to } 5 \% \\
(\mu \mathrm{m})\end{array}$ & $\begin{array}{c}\text { Mean } \pm \text { SD } \\
(\mu \mathrm{m})\end{array}$ & $\begin{array}{c}\text { CI to } 5 \% \\
(\mu \mathrm{m})\end{array}$ & $(\mu \mathrm{m})$ & $\begin{array}{c}\text { Mean } \pm \text { SD } \\
(\mu \mathrm{m})\end{array}$ & $\begin{array}{c}\text { CI to } 5 \% \\
(\mu \mathrm{m})\end{array}$ & \\
\hline Eucalyptus alba & $17.72 \pm 0.98$ & $17.33-18.10$ & $26.35 \pm 1.05$ & $25.94-26.76$ & 0.67 & $2.11 \pm 0.12$ & $2.03-2.80$ & Oblate \\
\hline Eucalyptus sp. I & $15.39 \pm 0.69$ & $15.12-15.70$ & $25.74 \pm 0.85$ & $25.41-26.08$ & 0.60 & $1.69 \pm 0.27$ & $1.53-1.86$ & Oblate \\
\hline Eucalyptus sp. II & $17.38 \pm 0.91$ & $17.02-17.70$ & $26.60 \pm 0.89$ & $26.25-26.95$ & 0.65 & $2.40 \pm 0.50$ & $2.09-2.70$ & Oblate \\
\hline Eucalyptus torelliana & $15.95 \pm 1.46$ & $15.38-16.50$ & $26.76 \pm 1.31$ & $26.24-27.27$ & 0.60 & $1.53 \pm 0.15$ & $1.44-1.63$ & Oblate \\
\hline Eugenia uniflora & $10.98 \pm 0.78$ & $10.68-11.30$ & $17.08 \pm 1.25$ & $16.59-17.57$ & 0.64 & $1.17 \pm 0.12$ & $1.09-1.24$ & Oblate \\
\hline Psidium araca & $16.73 \pm 0.83$ & $16.40-17.10$ & $23.33 \pm 1.05$ & $22.91-23.74$ & 0.72 & $1.59 \pm 0.16$ & $1.49-1.69$ & Oblate \\
\hline Psidium guajava & $10.39 \pm 0.77$ & $10.09-10.70$ & $16.69 \pm 0.55$ & $16.47-16.91$ & 0.62 & $1.26 \pm 0.13$ & $1.18-1.35$ & Oblate \\
\hline Syzygium cumini & $9.68 \pm 0.91$ & $9.33-10.00$ & $16.21 \pm 0.68$ & $15.94-16.47$ & 0.60 & $1.17 \pm 0.23$ & $1.03-1.31$ & Oblate \\
\hline Syzygium malaccensis & $8.76 \pm 0.76$ & $8.32-9.20$ & $17.00 \pm 0.87$ & $16.48-17.52$ & 0.52 & $1.12 \pm 0.12$ & $1.04-1.19$ & Oblate \\
\hline
\end{tabular}

$\mathrm{CI}=$ confidence interval, $\mathrm{ED}=$ equatorial diameter, $\mathrm{PD}=$ polar diameter and $\mathrm{SD}=$ standard deviation

medium size. A study of 140 Myrtaceae species from southern Brazil showed that all have in common the general palynological characteristics of this family, such as pollen grain of medium to small size, oblate to peroblate, 3-colporate of triangular $a m b$, surface granulated in mesocolpium and apocolpium, smoother around the apertures (24).

In the products of the hive Myrtaceae taxa are often identified (3-5). In a study conducted by Nascimento et al. (5) the pollen types E. uniflora and $P$. guajava occurred among samples of Apis mellifera Linnaeus, 1758 honey as predominant pollen and very frequent. Oliveira et al. (20) analyzed honey samples of Melipona scutellaris Latreille, 1811 verified the presence of pollen type Eucalyptus sp. classified as secondary pollen between the samples. In addition, these authors observed that only Melipona quadrifasciata anthidioides Lepeletier, 1836 collected trophic resources in E. uniflora in the studied area. These results indicate the relevance of this plant group as a source of trophic resources for social bees. In this way, a key to identify pollen of the species commonly represented in the pollen spectrum of bee products is presented below.

\section{Identification key of pollen grains of Myrtaceae species visited by social bees (Hymenoptera: Apidae (based on Table 3):}

1. Pollen grains with a polar diameter smaller than 12.00

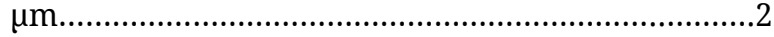

$1^{\prime}$. Pollen grains with a polar diameter greater than $12.00 \mu \mathrm{m}$ 5

2. Pollen grains with a polar diameter smaller than or equal to $10.00 \mu \mathrm{m}$ .3

2 '. Pollen grains with a polar diameter greater than $10.00 \mu \mathrm{m}$ . .4

3. Pollen grains with a polar diameter smaller than 9.20 $\mu \mathrm{m}$ and equatorial diameter between 16.48 and 17.52 


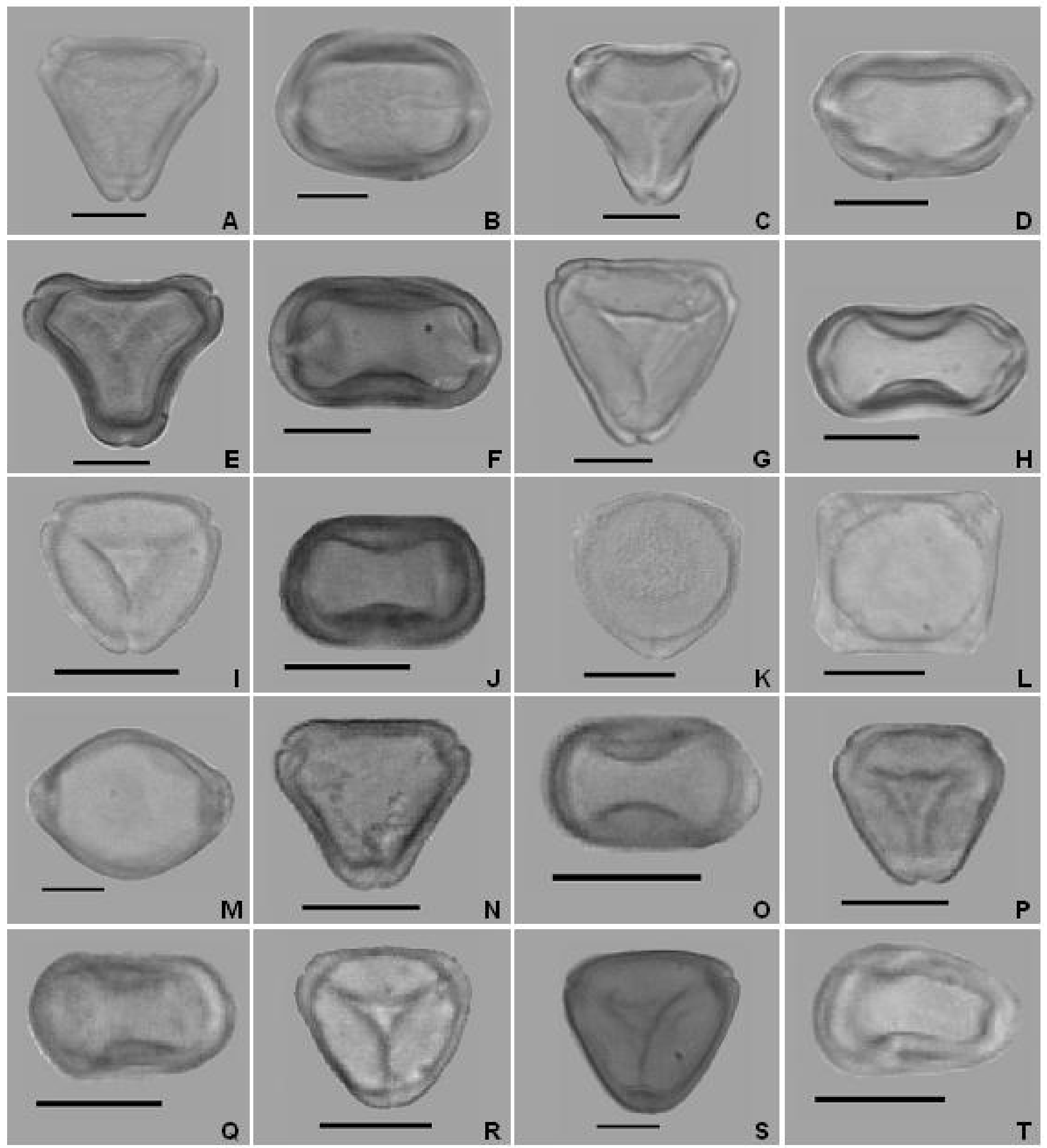

Fig. 1: Photomicrograph of pollen grains (1000x) of Myrtaceae species visited by social bees (Apidae) in Cruz das Almas, Recôncavo region of Bahia, Brazil, in equatorial view (EV) and polar view (PV) where: Eucalyptus alba Reinw A (PV) - B (EV); Eucalyptus sp.I C (PV) - D (EV); Eucalyptus sp.II E (PV) - F (EV); Eucalyptus torelliana F. Muell. G (PV) - H (EV); Eugenia uniflora L. I (PV) - J (EV); Psidium araca Raddi K-L (PV) - M (EV); Psidium guajava L. N (PV) - O (EV); Syzygium cumini (L.) Skeels P (PV) - Q (EV); Syzygium malaccensis L. R-S (PV) - T (EV). (Scale: $10 \mu \mathrm{m}$ ).

$\mu \mathrm{m}$; exine thickness between 1.04 and $1.19 \mu \mathrm{m}$ .. Syzygium malaccensis L. (Fig. 1 R-S).

3'. Pollen grains with a polar diameter between 9.30 and $10.00 \mu \mathrm{m}$ and equatorial diameter between 15.94 and $16.47 \mu \mathrm{m}$; exine thickness between 1.03 and 1.31 $\mu \mathrm{m}$. Syzygium cumini (L.) Skeels (Fig. 1 P-Q).

4. Pollen grain with triangular $a m b$ with the sides of the convex $a m b$; exine thickness between 1.09 and 1.24 $\mu \mathrm{m}$; polar diameter between 10.68 and $11.30 \mu \mathrm{m}$; equatorial diameter between 16.59 and 17.57 $\mu \mathrm{m}$. Eugenia uniflora L. (Fig. 1 I-J).

4 . Pollen grain with characteristic triangular $a m b$ or with the sides of the concave $a m b$; exine thickness between 1.18 and $1.35 \mu \mathrm{m}$; Polar diameter less than $10.70 \mu \mathrm{m}$; equatorial diameter between 16.47 and $16.91 \mu \mathrm{m}$ .Psidium guajava L. (Fig. $1 \mathrm{~N}-\mathrm{O}$ ). 


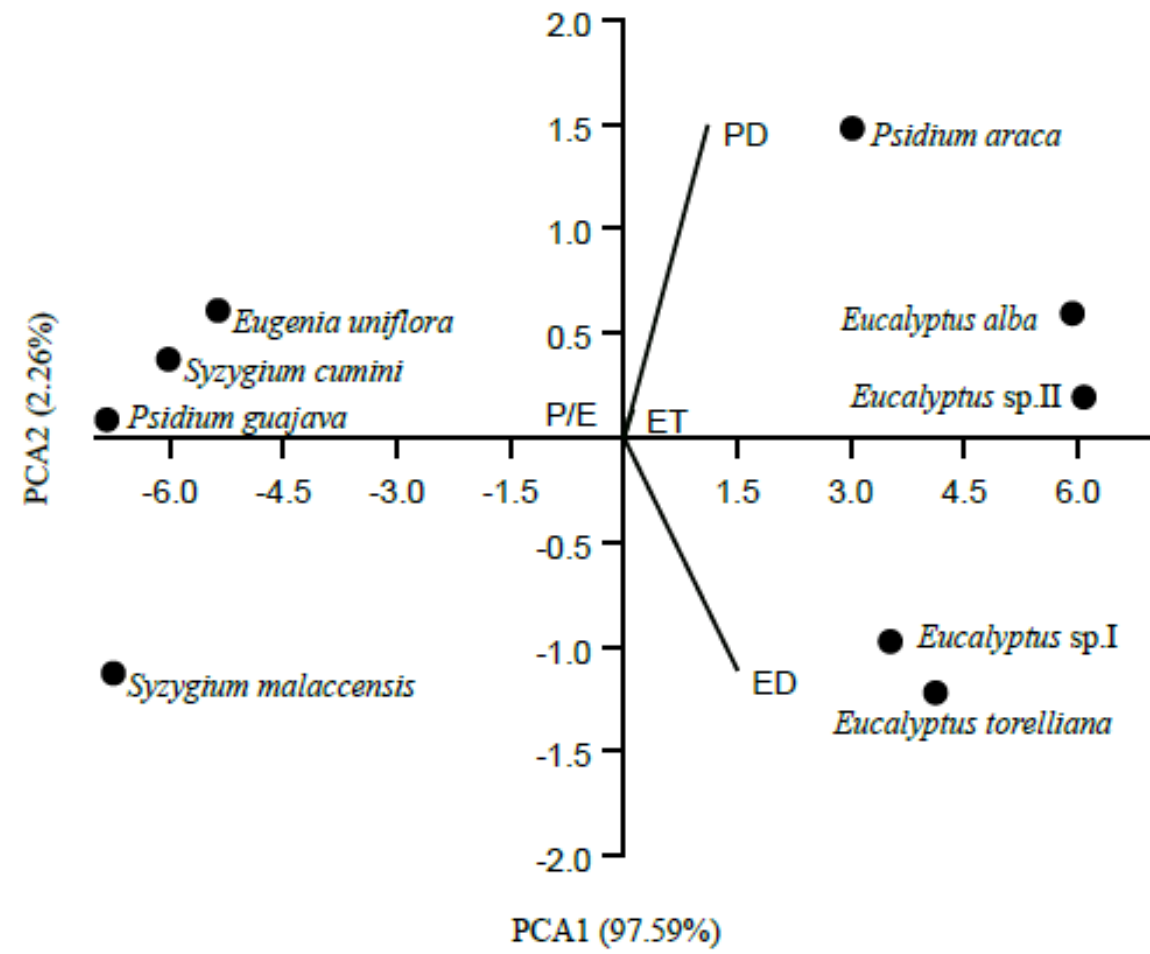

Fig. 2. Principal Component Analysis (PCA) of pollen grains of Myrtaceae species visited by social bees (Apidae) in Cruz das Almas, Recôncavo region of Bahia, Brazil. $\mathrm{ET}=$ exine thickness; $\mathrm{PD}=$ polar diameter; $\mathrm{ED}=$ equatorial diameter and $\mathrm{P} / \mathrm{E}=$ $\mathrm{P} /$ E ratio.

Table 4. Euclidean distance matrix (EDM) of pollen grains of Myrtaceae species visited by social bees (Apidae) in Cruz das Almas, Recôncavo region of Bahia, Brazil.

\begin{tabular}{|c|c|c|c|c|c|c|c|c|}
\hline & $\begin{array}{c}\text { Eucalyptus } \\
\text { alba }\end{array}$ & $\begin{array}{c}\text { Eucalyptus } \\
\text { sp.I }\end{array}$ & $\begin{array}{c}\text { Eucalyptus } \\
\text { sp.II }\end{array}$ & $\begin{array}{c}\text { Eucalyptus } \\
\text { torelliana }\end{array}$ & $\begin{array}{l}\text { Eugenia } \\
\text { uniflora }\end{array}$ & $\begin{array}{l}\text { Psidium } \\
\text { araca }\end{array}$ & $\begin{array}{l}\text { Psidium } \\
\text { guajava }\end{array}$ & $\begin{array}{c}\text { Syzygium } \\
\text { cumini }\end{array}$ \\
\hline Eucalyptus sp.I & 2.64 & & & & & & & \\
\hline Eucalyptus sp.II & 2.06 & 2.49 & & & & & & \\
\hline Eucalyptus torelliana & 3.56 & 2.32 & 1.96 & & & & & \\
\hline Eugenia uniflora & 12.18 & 10.18 & 11.71 & 10.93 & & & & \\
\hline Psidium araca & 5.95 & 4.86 & 4.56 & 4.05 & 8.56 & & & \\
\hline Psidium guajava & 13.56 & 11.49 & 12.82 & 11.89 & 2.12 & 9.24 & & \\
\hline Syzygium cumini & 14.74 & 12.64 & 13.92 & 12.91 & 3.38 & 10.23 & 1.32 & \\
\hline Syzygium malaccensis & 15.25 & 13.03 & 14.29 & 13.12 & 4.58 & 10.62 & 2.60 & 1.57 \\
\hline
\end{tabular}

5. Pollen grains with an equatorial diameter greater than $24.00 \mu \mathrm{m}$ 6

5 '. Pollen grains with an equatorial diameter smaller than $24.00 \mu \mathrm{m}$ 9

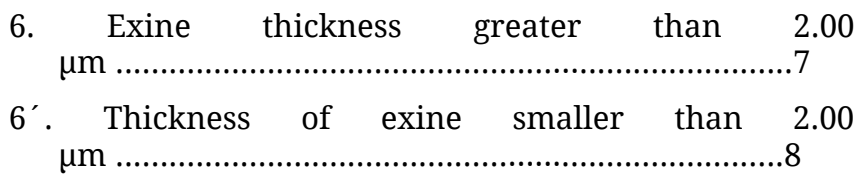

7. Pollen grains with exine thickness smaller than $2.15 \mu \mathrm{m}$; polar diameter between 17.33 and $18.10 \mu \mathrm{m}$; equatorial diameter between 25.94 and $26.76 \mu \mathrm{m}$; the $\mathrm{P} / \mathrm{E}$ ratio equals to $0.67 \mu \mathrm{m}$ Eucalyptus alba Reinw (Fig. 1 A-B).

7 . Pollen grains with exine thickness greater than 2.15 $\mu \mathrm{m}$; polar diameter between 17.02 and $17.70 \mu \mathrm{m}$; equatorial diameter between 26.25 and $26.95 \mu \mathrm{m}$; the P/ E ratio equals to $0.65 \mu \mathrm{m}$... Eucalyptus sp.II (Fig. 1 E-F).

8. Pollen grains with exine thickness equals to 1.69 $\mu \mathrm{m}$; polar diameter between 15.12 and 15.70 $\mu \mathrm{m}$; equatorial diameter between 25.41 and $26.08 \mu \mathrm{m}$ Eucalyptus sp.I (Fig. 1 C-D).

8'. Pollen grains with exine thickness equals $1.53 \mu \mathrm{m}$; polar diameter between 15.38 and $16.50 \mu \mathrm{m}$; equatorial diameter between 26.24 and 27.27 $\mu \mathrm{m}$.......... Eucalyptus torelliana F. Muell (Fig. $1 \mathrm{G}-\mathrm{H}$ ). 
9. Pollen grains with polar diameter between 16.40 and $17.10 \mu \mathrm{m} ; \mathrm{P} / \mathrm{E}=0.72$; exine thickness equals to 1.59 $\mu \mathrm{m}$ Psidium araca Raddi. (Fig. $1 \mathrm{~K}-\mathrm{L}$ ).

\section{Conclusion}

The description of pollen morphology of the Myrtaceae species reveals similarity between the several characteristics common to pollen grains of species of this family. This description allows separation of nine species studied by size and specific morphological features with the identification key, which can be used to study the pollen spectrum of beehive products.

\section{Competing Interests}

The authors declare no conflict of interests.

\section{Author's contributions}

ASN (ORCID: https://orcid.org/0000-0001-52360460) carried out fieldwork and compiled the data. ASN and CALC (ORCID: https://orcid.org/0000-00023306-3003) conceptualized the work plan and structured the manuscript.

\section{Acknowledgements}

This study was financed in part by the "Coordenação de Aperfeiçoamento de Pessoal de Nível Superior - Brasil” (CAPES) - Funding Code 001 and by the "Fundação de Amparo à Pesquisa do Estado da Bahia" (FAPESB) - Funding Code PAM0004/2014. We thank the "Conselho Nacional de Desenvolvimento Científico e Tecnológico” (CNPq) for granting a scholarship to CALC (No. 305885/2017-0). AS Nascimento wishes to thank CAPES for the postdoctoral scholarship (PNPD20130760).

\section{References}

1. Adhikari S, Ranabhat N. Bee flora in mid hills of Central Nepal. Botanica Orientalis: Journal of Plant Science. 2012; 8: 45-56. https://doi.org/10.3126/botor.v8i0.5558

2. Kumar R, Rajput GS, Mishra RC, Agrawal OP. A study on assessment of duration of dearth period for Honey bees in Haryana, India. Munis Entomology Zoology. 2013; 8: 434-437.

3. Santana ALA, Fonseca AAO, Alves RMO, Carvalho CAL, Melo PA, Silva ES, Souza BA, Jesus JN, Sodré GS. Pollen types in honey samples of stingless bees from municipalities in the semiarid baiano. Magistra. 2011; 23: 134-139. https://core.ac.uk/download/pdf/45502490.pdf

4. Nascimento AS, Carvalho CAL, Martins MLL. Plants visited by Apis mellifera L. (Hymenoptera: Apidae) in Recôncavo Baiano, State of Bahia, Brazil. Revista de Agricultura, Piracicaba. 2014; 89: 97-116.
5. Nascimento AS, Carvalho CAL, Sodré GS. The pollen spectrum of Apis mellifera honey from Reconcavo of Bahia, Brazil. Journal of Scientific Research and Reports. 2015; 6: 426-438. https://doi.org/10.9734/JSRR/2015/16799

6. Marques LJP, Muniz FH, Lopes GS, Silva JM. (2011). Levantamento da flora apícola em Santa Luzia do Paruá, Sudoeste da Amazônia, Maranhão. Acta Botanica Brasilica. 2011; 25: 141-149. https://dx.doi.org/ $\underline{10.1590 / \mathrm{S} 0102-33062011000100017}$

7. Morais LMF, Conceição GM, Nascimento JM. Family Myrtaceae: morphological analysis and geographical distribution of a botanical collection. Agrarian Academy. 2014; 1: 1-5.

8. Lima DF, Caddah MK, Goldenberg R. The family Myrtaceae at Ilha do Mel, Paranaguá, Paraná State, Brazil. Hoehnea. 2015; 42: 497-519. http://dx.doi.org/10.1590/2236-8906-68/2014

9. Oliveira EF, Bezerra DG, Santos ML, Rezende MH, Paula JAM. Leaf morphology and venation of Psidium species from the Brazilian Savanna. Revista Brasileira de Farmacognosia. 2017; 27: 407-413. http://dx.doi.org/10.1016/j.bjp.2017.03.005

10. Bünger M, Stehman JR, Oliveira-Filho AT. Myrtaceae throughout the Espinhaço Mountain Range of centraleastern Brazil: floristic relationships and geoclimatic controls. Acta Botanica Brasilica. 2014; 28: 109-119. $\quad$ http://dx.doi.org/10.1590/S0102$\underline{33062014000100011}$

11. Sobral M, Faria Jr JEQ, Oliveira MIL, Lucas EJ, Rigueira D, Stadnik A, Villaroel D. Thirteen new Myrtaceae from Bahia, Brazil. Phytotaxa. 2015; 224: 201-231. http://dx.doi.org/10.11646/phytotaxa.224.3.1

12. Wilson PG. Myrtaceae. In: Kubitzki K. 1st ed. Flowering plants. Eudicots: The families and genera of vascular plants. Springer: Berlin; 2011. p.212-271.

13. Cronquist A. An integrated system of classification of flowering plants. Columbia University Press: New York; 1981.

14. El-Shenawy SMA. Biological Activities of Eugenia jambolana (Family Myrtaceae) Seeds. In: Preedy V, Watson R, Patel V. Nuts and Seeds in Health and Disease Prevention. 1st ed. Elservier: New York; 2011. p.685-691.

15. Singh SP. (2011). Guava (Psidium guajava L.). In: Mango C. Postharvest Biology and Technology of Tropical and Subtropical Fruits, 1st ed. Elservier: New York; 2011. p.213-246e.

16. Lorenzi H. Árvores Brasileiras: Manual de identificação e cultivo de plantas arbóreas nativas do Brasil. Plantarum: Nova Odessa; 1992

17. Almeida-Anacleto D, Marchini LC, Moreti ACCC, Souza VC. Plants used by bees as pollen sources in the brazilian "Cerrado". Sociobiology. 2012; 59: 1483-1493. http://dx.doi.org/10.13102/sociobiology.v59i4.521

18. Foelkel CEB. Os eucaliptos utilizados para a produção de mel - uma apicultura de excelente qualidade. Eucalyptus Online Book \& Newsletter; 2008.

19. Barth OM. Análise polínica de mel: avaliação de dados e seu significado. Mensagem Doce. 2005; 81: 1-4.

20. Oliveira DJ, Carvalho CAL, Sodré GS, Paixão JF, Alves RMO. Partitioning of pollen resources by two stingless bee species in the North Bahia, Brazil. Grana. 2016; 56: 285-293.

https://doi.org/10.1080/00173134.2016.1217040 
21. Souza LS, Lucas CIS, Conceição PJ, Paixão JF, Alves RM. Pollen spectrum of the honey of uruçu bee (Melipona scutellaris Latreille, 1811) (Hymenoptera: Apidae) in the North Coast of Bahia State. Acta Scientiarum. 2015; 37: 483-489. http://dx.doi.org/10.4025/actascibiolsci.v37i4.28059

22. Silvia CI, Ballesteros PLO, Palmero MA, Bauermann SG, Evaldt ACP, Oliveira PE. Palinologia aplicada em estudos de conservação de abelhas do gênero Xylocopa no Triângulo Mineiro. Edufu: Uberlândia; 2010.

23. Erdtman G. The acetolysis method. A revised description. Svensk Botanisk Tidskrift, Stockholm. 1960; 39: 561-564.

24. Punt W, Hoen PP, Blackmore S, Nilsson S, Le Thomas A. Glossary of pollen and spores terminology. Review of Palaeobotany and Palynology. 2007; 143: 1-81. https://doi.org/10.1016/j.revpalbo.2006.06.008

25. Barth OM, Melhem TS. Glossário ilustrado de palinologia. Unicamp: Campinas; 1998.

26. Barth OM, Barbosa AF. Catálogo sistemático dos polens das plantas arbóreas do Brasil Meridional XV Myrtaceae. Memórias do Instituto Oswaldo Cruz: Rio de Janeiro; 1972.

27. Hammer $\emptyset$, Harper DAT, Ryan PD. PAST: Paleontological Statistics software package for education and data analysis. Paleontologica Eletronica. 2001; 4: 1-9. http://palaeo-electronica.org/2001 1/past/issue1 01.htm

28. Thornhill AH, Hope GS, Craven LA, Crisp MD. Pollen morphology of the Myrtaceae. Part 2: tribes Backhousieae, Melaleuceae, Metrosidereae, Osbornieae and Syzygieae. Australian Journal of Botany. 2012; 60, 200-224. http://dx.doi.org/10.1071/BT11175

29. Thornhill AH, Wilson PG, Drudge J, Barrett MD, Hope Hope GS, Craven LA, Crisp MD. Pollen morphology of the Myrtaceae. Part 3: tribes Chamelaucieae, Leptospermeae and Lindsayomyrteae. Australian Journal of Botany. 2012; 60, 225-259. http://dx.doi.org/10.1071/BT11176
30. Thornhill AH, Hope GS, Craven LA, Crisp MD. Pollen morphology of the Myrtaceae. Part 4: tribes Kanieae, Myrteae and Tristanieae. Australian Journal of Botany. 2012; 60, 260-289. http://dx.doi.org/10.1071/BT11177

31. Silva CI, Imperatriz-Fonseca VL, Groppo M, Bauermann SG, Saraiva AM, Queiroz EP, Valdt ACP, Aleixo KP, Castro JP, Castro MMN, Faria LB, Caliman MJF, Wolff JL, Paulino Neto HF, Garófalo CA. Catálogo polínico das plantas usadas por abelhas no campus da USP de Ribeirão Preto. Holos: Ribeirão Preto; 2014.

32. Erdtman G. Pollen Morphology and plant Taxonomy. Angiosperms. Chronica Botanica: Stockholm; 1952.

33. Lain CS. Glosario de términos palinológicos. Lazaroa. 2004; 25: 93-112.

34. Barth OM. O pólen no mel brasileiro. Luxor: Rio de Janeiro; 1989.

35. Melhem TS, Cruz-Barros MAV, Corrêa MAS, MakinoWatanabe H, Silvestre-Capelato MSF, Esteves VLG. Variabilidade polínica em plantas de Campos do Jordão (São Paulo, Brasil). Boletim do Instituto de Botânica: São Paulo; 2003.

36. Takeda IJM, Souza MKF, Farago PV, Gelisnski VV. Catálogo polínico do Parque Estadual de Vila Velha Paraná - $3^{\mathrm{a}}$ Parte. Arquivos de Ciências da Saúde da Unipar. 2002; 6: 61-66 https://doi.org/10.25110/arqsaude.v6i3.2002.1183

37. Matos MNF, Maduro CB, Costa CS, Silva SJR. Palynological characterization of wood plants from Bosque dos Papagaios, Boa Vista, Roraima, North Brazil. Boletim do Museu Integrado de Roraima. 2014; 8: 19-41.

38. Tuler AC, Silva T, Carrijo TT, Garbin ML, Mendonça CBF, Peixoto AL, Gonçalves-Esteves V. Taxonomic significance of pollen morphology for species delimitation in Psidium (Myrtaceae). Plant Systematics and Evolution. 2017; 303: 317-327. https://doi.org/10.1007/s00606-016-1373-8 